\title{
RESEARCHES ON THE DESIGN, EXECUTION AND TESTING OF A FINE BUBBLE GENERATOR
}

\author{
Nicolae Băran ${ }^{1}$, Gheorghe I.Gheorghe ${ }^{2}$, Octavian Donțu${ }^{3}$, Daniel Besnea ${ }^{4}$, Ion Durbacă $\breve{a}^{5}$, \\ Elena Beatrice Tănase6, Mihaela Constantin ${ }^{7}$, Corina Ioana Moga ${ }^{8}$ \\ 1,3-8 Politehnica University of Bucharest \\ ${ }^{2}$ National Institute of Research and Development in Mechatronics and \\ Measurement Technique, Bucharest \\ E-mail: $\underline{n}$ baran fimm@yahoo.com,geocefin@yahoo.com,octavdontu@yahoo.com, d.bes@yahoo.com, \\ ion.durbaca@yahoo.com,tanaseelenab@gmail.com,.i.mihaelaconstantin@gmail.com,.corinamoga@yahoo.com
}

\begin{abstract}
The paper presents an original solution of a fine air bubble generator (FBG) that is used for water aeration. The calculation of the oriffices number and their diameter is indicated, orifices appearing in the perforated plate to be mounted on the fine bubble generator. The constructive solution of the fine bubble generator is presented, and the results of the experimental researches on water aeration using this fine bubble generator are presented.
\end{abstract}

Keywords: Water aeration, Fine bubble generator, Oxygen dissolved in water.

\section{Introduction}

The issue of reducing water pollution is topical and requires a solution with minimal energy consumption. Between the mechanical and pneumatic aeration the most favorable is pneumatic aeration which can be achieved by [1] [2] [3]:

- the use of porous diffusers built of ceramic, plastic, elastic materials.

- installation of pipes with $\emptyset 1-3 \mathrm{~mm}$ orifices on the tank foundation.

- the construction of fine bubble generators with $\emptyset<1 \mathrm{~mm}$ orifices .

By aerating the water, it is intended to increase the amount of dissolved oxygen in water, which favors the existence of aquatic life.

The amount of dissolved oxygen required varies from an aquatic living organism to another. Crabs, oysters and worms need minimal amounts of oxygen $(1 \div 6 \mathrm{mg} / \mathrm{dm} 3)$, while fish in shallow water need a higher level $(4 \div 15 \mathrm{mg} / \mathrm{dm} 3)$.

Unconventional technologies have been used to construct fine bubble generators $[4,5]$. Thus, the orifices of the plates for the fine bubble generators were made by spark-erosion and micro-drilling. Orifices of $\emptyset 0.1 \mathrm{~mm}$, were made through microdrilling, and $\varnothing 0.3 \mathrm{~mm}$ and $\emptyset 0.5 \mathrm{~mm}$ through sparkerosion. Aeration systems are effective when it generate fine gas bubbles and ensure a uniform distribution of the injected air in water. By performing the most efficient aeration systems, it reduces the electricity consumption in the air compressors stations which infuses air into the water.

The oxygenation process is based on a transfer between air and water; the oxygen in the air is transferred by different processes to the water. The air bubbles generated by the equipment that forms it are introduced into a water volume. The most efficient systems for water oxygenation are those that generate very fine bubbles [6] [7] [8].

The performance of a water oxygenation system is characterized by two parameters: process;

- the efficiency of the water oxygenation

- efficiency of water oxygenation.

The two parameters are influenced by the efficiency of air dispersing devices in water.

\section{The influence of the Air Introduction Orifice Diameter in Water of Dissolved Oxygen Concentration in Water}

The smaller the orifice that produces the air bubble, the smaller the bubble which emerges from the orifice. Specialty studies concern important aspects of the constructive solutions of the fine bubble generators and the materials from which they are obtained, as well as aspects regarding the influence of the constructive solution of the fine bubble generators on the dissolved oxygen concentration in the water.

The most important element of fine bubble generators is the air dispersing element in water, which can be constructed in various forms (circular, rectangular, tubular, spherical, etc.) and can be made 
of materials (glass, plastics, rubber, shape memory materials, etc.) that meet certain operating criteria.

The rate of oxygen transfer to water in the case of a pneumatic aeration system is [9] [10]:

$$
\frac{d C}{d \tau}=a k_{L}\left(C_{s}-C\right)
$$

where: Cs is the mass concentration of oxygen at saturation in the liquid phase $\left[\mathrm{mg} / \mathrm{dm}^{3}\right]$;

$\mathrm{C}$ - the mass concentration of oxygen in the liquid phase $\left[\mathrm{mg} / \mathrm{dm}^{3}\right]$;

$\mathrm{ak}_{\mathrm{L}}$ - the volumetric mass transfer coefficient $[\mathrm{s}$ 1];

$\mathrm{k}_{\mathrm{L}}$ - global mass transfer coefficient $[\mathrm{m} / \mathrm{s}]$;

a - interfacial specific area $\left[\mathrm{m}^{2} / \mathrm{m}^{3}\right]$.

The interfacial specific area of the bubbles is defined as the ratio between the area $A$ of the gas bubbles and the volume $\mathrm{V}$ of the biphasic system (air + water) [11] [12]:

$$
a=\frac{A}{V}\left[\frac{m^{2}}{m^{3}}\right]
$$

From equation (2) it can be seen that the intensification of the mass transfer of oxygen to the water, i.e. the increase of the oxygen transfer rate can occur by achieving a larger surface of interphase contact; this requires the production of air bubbles of the smallest diameter. For fine bubbles $(\varnothing<1$ $\mathrm{mm}$ ), aeration is more efficient than that made with coarse bubbles, because the specific interface area between air and water is greater.

\section{Establishing the Architecture of the Orifice Plate and the Fine Bubble Generator}

A orifice in the perforated plate of FBG, if it has a small diameter, generates small air bubbles, which influences the transfer of oxygen to water through three paths:

- increasing the air bubble surface per unit volume will increase the interfacial specific area, so $\mathrm{ak}_{\mathrm{L}}$;

- lowering the ascending speed of the air bubble and thereby increasing the contact time between air bubble and water, resulting in increase of $\mathrm{dC} / \mathrm{d} \tau$;

- for constant air flow $\dot{V}=c t$, will increase the number of air bubbles generated by each orifice.

In the field of water oxygenation it is known that the lower the diameter of the gas bubble (air), the higher the rate of oxygen transfer to the water [1113].
On this line, the results of the theoretical researches on the performance of the fine bubble generators built by special technologies are presented.

Thus, the plates with orifices of the fine bubble generators were made by micro-drilling. Perforated plates with orifices of $\emptyset 1=0.1 \mathrm{~mm}$ were made by micro-drilling. With the notations in figure 1 , the design and construction of FBG the following two conditions must be fulfilled [13] [14]:

$$
\begin{aligned}
& \mathrm{I} \rightarrow \frac{s}{d_{0}}>3 \\
& \mathrm{II} \rightarrow \frac{d}{d_{0}}>8
\end{aligned}
$$

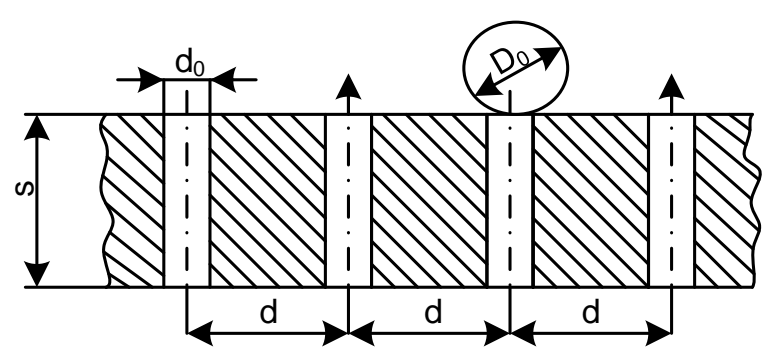

Figure 1: Plate with orifices for air dispersing in water $d_{0}$ - orifice diameter, $d_{0}=2 r_{0} ; D_{0}$ - diameter of the gas bubble at the outlet of the orifice (when it is detached); $s$ - thickness of the perforated plate

Through experimental researches the following has been chosen:

$$
\begin{aligned}
& \text { I. } d_{0}=0.1 \mathrm{~mm} \\
& \frac{s}{d_{0}}=\frac{2}{0.1}=20 \\
& \frac{d}{d_{0}}=\frac{2}{0.1}=20
\end{aligned}
$$

From the previous researches [15] [16] [17] and taking into account the architecture of the experimental researches instalation for the FBG, a section of the air outlet in the water area of: $A=1.2 \cdot 10^{-6} \mathrm{~m}^{2}$ was chosen.

The number of orifices in the perforated plate of FBG with $\mathrm{d}_{0}=0.1 \mathrm{~mm}$ will be:

$$
n_{0.1}=\frac{A}{\frac{\pi \cdot d_{0}^{2}}{4}}=\frac{1.20 \cdot 10^{-6}}{0.785 \cdot\left(0.1 \cdot 10^{-3}\right)^{2}}=152
$$

Figure 2 shows the plate with orifices. 


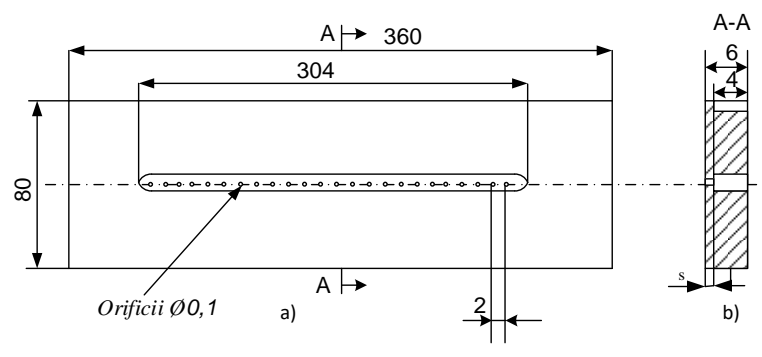

Figure 2: Plate with orifices of a FBG

a) Top view; b) Cross section

To form the orifices in the plate (Figure 2), a 4 $\mathrm{mm}$ high and $304 \mathrm{~mm}$ long alveolar channel was created. Subsequently, with a special microprocessing machine, 152 orifices with $\emptyset 0.1 \mathrm{~mm}$ were made in the channel. This machine has an accuracy of $\pm 0.5 \mu \mathrm{m}$, which has ensured the creation of a FBG which is an original construction solution.

Figure 3 shows the microscope with which the process was controlled. The microscope was fixed to the fine bubble generator. The orifices are perfectly circular (Figure 4), which provides a round air jet that penetrates into the water.

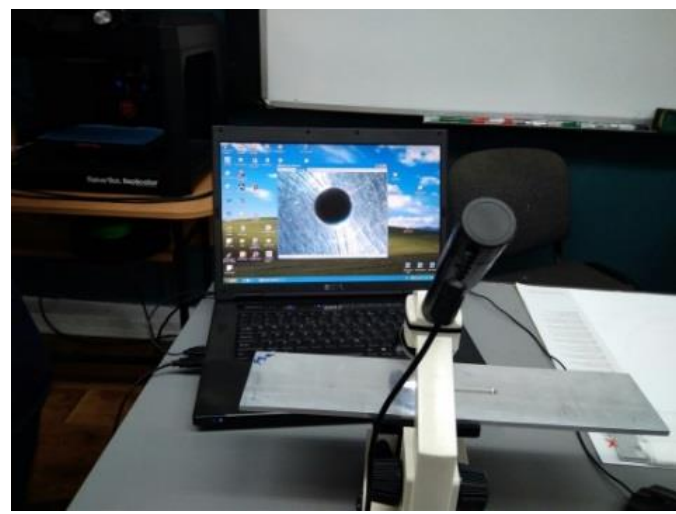

Figure 3: Microscope for studying profiles with magnification range from $40 x$ to $20 x$

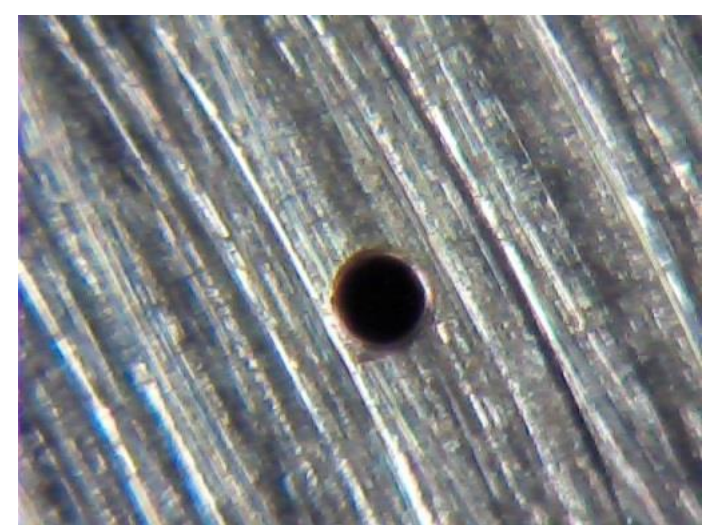

Figure 4: $6 \mathrm{~mm}$ thick duralumin plate with $\varnothing 0.1 \mathrm{~mm}$ orifices

Figure 5 shows an overview of FBG; fixing the plate with orifices (3) to the body of the FBG (1) is carried out by means of a special shape gasket (2).

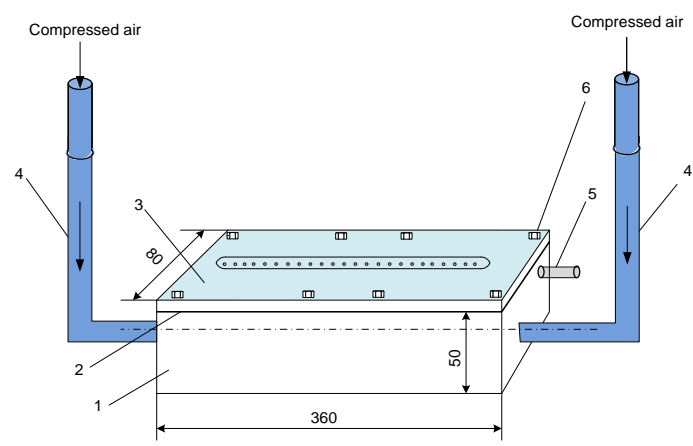

Figure 5: Fine air bubble generator

1 - compressed air tank; 2 - sealing gasket; 3 - orificeplate; 4 - compressed air supply pipe of FBG $\emptyset 18 \mathrm{~mm}$; 5 - compressed air pressure connection; 6 screws for fixing the plate with orifices in the tank frame

\section{Theoretical Researches on the use of this Type of fine Bubble Generator to Increase the Concentration of Oxygen Dissolved in Water}

Based on the computational program built to solve the air-to-water oxygen-to-water oxygen equation (relation 1) using the Euler method, presented in [18], [19], the curve of the variation of the dissolved $\mathrm{O}_{2}$ concentration in water in time for the FBG constructive version with orifices of $0.1 \mathrm{~mm}$. Following the running of the calculation program for the FBG the $\mathrm{C}=\mathrm{f}(\mathrm{t})$ curve shown in Figure 6 was constructed (Initial data: $V=600 \mathrm{dm}^{3} / \mathrm{h} ; C_{0}=5.48$ $\mathrm{mg} / \mathrm{dm}^{3} ; \tau=120 \mathrm{~min} ; t_{\mathrm{H}_{2} \mathrm{O}}=24{ }^{\circ} \mathrm{C} ; C_{s}=8.4$ $\mathrm{mg} / \mathrm{dm}^{3}$ ).

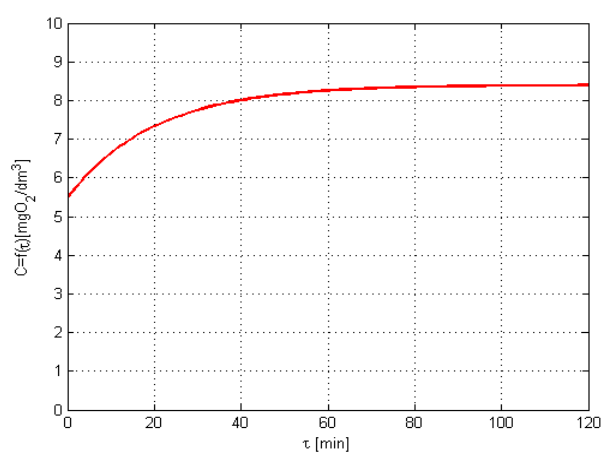

Figure 6: The variation of the dissolved oxygen concentration in water in time for FBG with $\emptyset 0.1 \mathrm{~mm}$ orifices

\section{Experimental Researches}

5.1. The experimental installation for the injection of air from the atmosphere into the water

The scheme shown in Figure 7 provides air supply to the fine bubble generator (8) located at the bottom of the water tank (6). 


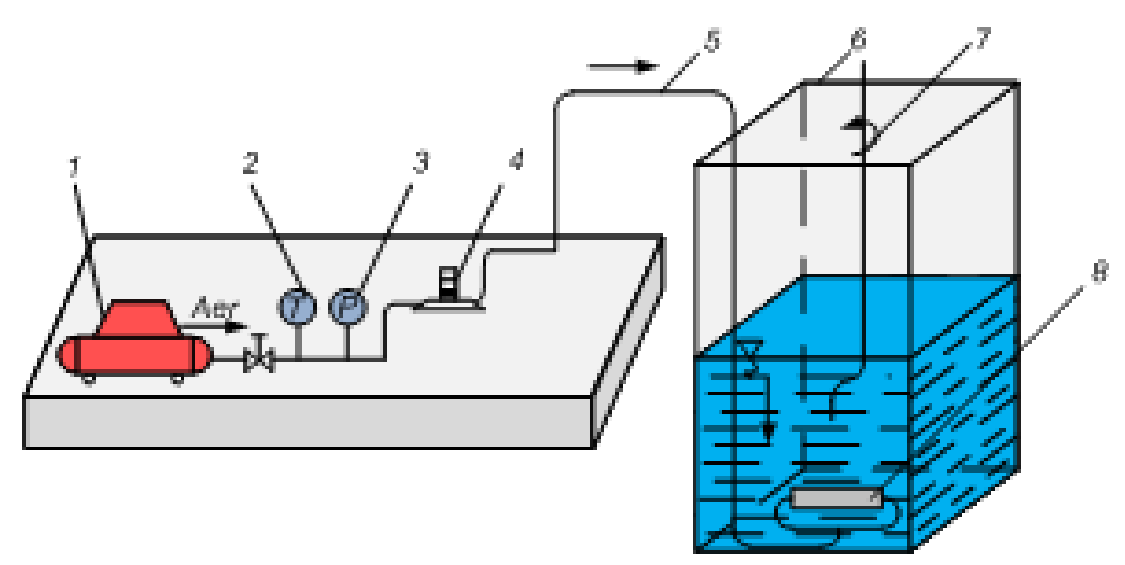

Figure 7: The experimental installation scheme for the injection of atmospheric air into water: 1 -air compressor; 2 - temperature measuring devices; 3 -gas pressure gauge; 4 - rotameter; 5 - pipe for the transport of the compressed air to the M.B.G.; 6 - parallelepiped water tank;

7 -oxygenometer probe; 8 - fine bubble generator with 152 orifices $\emptyset 0.1 \mathrm{~mm}$

Figure 7 shows that after compressing the air, the temperature, the pressure and the air flow rate are measured; afterwards it is introduced in FBG with parameters: $\mathrm{p}=573 \mathrm{~mm} \mathrm{H}_{2} \mathrm{O}, \dot{V}=600 \mathrm{dm}^{3} / \mathrm{h}$.

The duration of the experiments is 2 hours, during which the dissolved oxygen concentration in water increases from $\mathrm{C}_{0}$ to $\mathrm{C}_{5}$.

Taking into account the volumetric flow of the gas, an air velocity is produced through the feed line of the FBG [20][21]:

$$
\begin{aligned}
w=\frac{\dot{V}}{A}=\frac{\dot{V}}{\frac{\pi \cdot d_{i}^{2}}{4}} & =\frac{600 \cdot 10^{-3}}{3600} \cdot \frac{1}{0.785 \cdot(0.012)^{2}} \\
w & =1.474 \mathrm{~m} / \mathrm{s}
\end{aligned}
$$

\subsection{Researches methodology}

The measurements involve the following steps:

1. Verification if the 152 orifices are working, i.e. the air is introduced into the fine bubble generator; $\mathrm{H}_{2} \mathrm{O}$;

2. The tank filling with water up to $\mathrm{H}=500 \mathrm{~mm}$

3. The measurements of $\mathrm{C}_{0}, \mathrm{t}_{\mathrm{H} 2 \mathrm{O}}, \mathrm{t}_{\mathrm{air}}$;

4. The introduction of the fine bubble generator and the time notation $(\tau)$;

5. The removal of the FBG every 15 minutes outside the tank, and the measurement of the dissolved oxygen concentration.

6. When a horizontal plane of function $C=f(\tau)$ is reached, the measurements stops with the condition: $\mathrm{C} \approx \mathrm{Cs}$;

7. From previous research [13, 14], the concentration of dissolved oxygen in water tends to saturation after a two-hour period. So, the oxygen concentration will be measured at times: 15 minutes; 30 minutes; 45 minutes; 60 minutes; 75 minutes; 90 minutes; 105 minutes; 120 minutes.

8. At the end of the measurements, the oxygen probe is cleaned and the water from the tank is emptied.

The purpose of experimental researches is to validate or not the graph of the function in Figure 6.

Before performing the measurements, it was stated:

$$
\begin{aligned}
& \mathrm{C}_{0}=5.84 \mathrm{mg} / \mathrm{dm}^{3} ; \\
& \mathrm{t}_{\mathrm{H} 2 \mathrm{O}}=24^{\circ} \mathrm{O} ; \\
& \mathrm{t}_{\mathrm{air}}=24.1^{\mathrm{o}} \mathrm{C} .
\end{aligned}
$$

\subsection{Oxygen concentration at saturation $C s$}

Saturation concentration values of oxygen in water are dependent on: water temperature, product concentrations present in water, salinity of water, pressure at mass transfer, air composition and oxygen concentration which diffuses into the water.

Temperature affects most physical, chemical and biological processes involved in the aeration process.

In the aeration process the temperature influences the oxygen regime in the water, the intensity of the bacterial decomposition processes, the degree of toxicity of some substances, etc.

Temperature influences both saturation concentration and mass transfer coefficient. Water temperature directly influences saturation concentration, saturation concentration according to water temperature at atmospheric pressure $\mathrm{p}_{\text {at }}=$ $760 \mathrm{~mm} \mathrm{Hg}$, varies with temperature according to data in table 1. 
Table 1. Concentration variation at saturation with temperature at $p_{a t}=760 \mathrm{~mm} \mathrm{Hg}$

\begin{tabular}{|l|l|l|l|l|l|l|l|}
\hline $\mathrm{t}^{\circ} \mathrm{C}$ & $C_{s}$ & $\mathrm{t}^{\mathrm{O}} \mathrm{C}$ & $C_{s}$ & $\mathrm{t}^{\mathrm{O}} \mathrm{C}$ & $C_{s}$ & $\mathrm{t}^{\circ} \mathrm{C}$ & $C_{s}$ \\
\hline 0.0 & 14,60 & $\mathbf{1 0 , 0}$ & 11,30 & $\mathbf{2 0 , 0}$ & 9,10 & $\mathbf{3 0 , 0}$ & 7,50 \\
\hline 0.5 & 14,40 & $\mathbf{1 0 , 5}$ & 11,10 & $\mathbf{2 0 , 5}$ & 9,00 & $\mathbf{3 0 , 5}$ & 7,50 \\
\hline 1.0 & 14,20 & $\mathbf{1 1 , 0}$ & 11,00 & $\mathbf{2 1 , 0}$ & 8,90 & $\mathbf{3 1 , 0}$ & 7,40 \\
\hline 1.5 & 14,00 & $\mathbf{1 1 , 5}$ & 10,90 & $\mathbf{2 1 , 5}$ & 8,80 & $\mathbf{3 1 , 5}$ & 7,30 \\
\hline 2.0 & 13,80 & $\mathbf{1 2 , 0}$ & 10,80 & $\mathbf{2 2 , 0}$ & 8,70 & $\mathbf{3 2 , 0}$ & 7,30 \\
\hline 2.5 & 13,60 & $\mathbf{1 2 , 5}$ & 10,60 & $\mathbf{2 2 , 5}$ & 8,60 & $\mathbf{3 2 , 5}$ & 7,20 \\
\hline 3.0 & 13,40 & $\mathbf{1 3 , 0}$ & 10,50 & $\mathbf{2 3 , 0}$ & 8,60 & $\mathbf{3 3 , 0}$ & 7,20 \\
\hline 3.5 & 13,30 & $\mathbf{1 3 , 5}$ & 10,40 & $\mathbf{2 3 , 5}$ & 8,50 & $\mathbf{3 3 , 5}$ & 7,10 \\
\hline 4.0 & 13,10 & $\mathbf{1 4 , 0}$ & 10,30 & $\mathbf{2 4 , 0}$ & 8,40 & $\mathbf{3 4 , 0}$ & 7,00 \\
\hline 4.5 & 12,90 & $\mathbf{1 4 , 5}$ & 10,20 & $\mathbf{2 4 , 5}$ & 8,30 & $\mathbf{3 4 , 5}$ & 7,00 \\
\hline 5.0 & 12,70 & $\mathbf{1 5 , 0}$ & 10,10 & $\mathbf{2 5 , 0}$ & 8,20 & $\mathbf{3 5 , 0}$ & 6,90 \\
\hline 5.5 & 12,60 & $\mathbf{1 5 , 5}$ & 10,00 & $\mathbf{2 5 , 5}$ & 8,20 & $\mathbf{3 5 , 5}$ & 6,90 \\
\hline 6.0 & 12,40 & $\mathbf{1 6 , 0}$ & 9,80 & $\mathbf{2 6 , 0}$ & 8,10 & $\mathbf{3 6 , 0}$ & 6,80 \\
\hline 6.5 & 12,30 & $\mathbf{1 6 , 5}$ & 9,70 & $\mathbf{2 6 , 5}$ & 8,00 & $\mathbf{3 6 , 5}$ & 6,80 \\
\hline 7.0 & 12,10 & $\mathbf{1 7 , 0}$ & 9,60 & $\mathbf{2 7 , 0}$ & 7,90 & $\mathbf{3 7 , 0}$ & 6,70 \\
\hline 7.5 & 12,00 & $\mathbf{1 7 , 5}$ & 9,50 & $\mathbf{2 7 , 5}$ & 7,90 & $\mathbf{3 7 , 5}$ & 6,70 \\
\hline 8.0 & 11,80 & $\mathbf{1 8 , 0}$ & 9,40 & $\mathbf{2 8 , 0}$ & 7,80 & $\mathbf{3 8 , 0}$ & 6,60 \\
\hline 8.5 & 11,70 & $\mathbf{1 8 , 5}$ & 9,30 & $\mathbf{2 8 , 5}$ & 7,70 & $\mathbf{3 8 , 5}$ & 6,60 \\
\hline 9.0 & 11,50 & $\mathbf{1 9 , 0}$ & 9,30 & $\mathbf{2 9 , 0}$ & 7,70 & $\mathbf{3 9 , 0}$ & 6,50 \\
\hline 9.5 & 11,40 & $\mathbf{1 9 , 5}$ & 9,20 & $\mathbf{2 9 , 5}$ & 7,60 & $\mathbf{3 9 , 5}$ & 6,50 \\
\hline
\end{tabular}

\subsection{Oxygen concentration at saturation $C s$}

Figure 8 shows the position of the FBG in the water tank. The FBG is supplied with compressed air through its two extremities.
Figure 9 shows the FBG in operation, the bubble jets create a fine bubble curtain.

The compressed air pressure $\left(p=573 \mathrm{~mm} \mathrm{H}_{2} \mathrm{O}\right)$ overcomes the hydrostatic pressure $(\mathrm{H}=500 \mathrm{~mm}$ $\mathrm{H}_{2} \mathrm{O}$ ) and air pressure loss through the FBG.

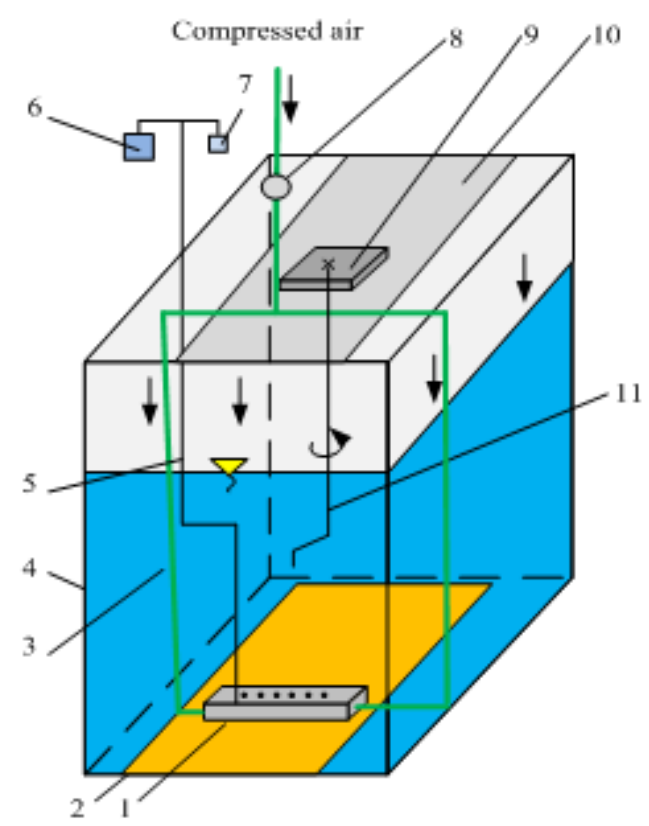

Figure 8: Installation of a FBG in the water tank

1 - G.B.F; 2 - support platform for FBG; 3 - compressed air pipe; 4 - water tank; 5 - pressure and temperature measurement connection in the body of FBG; 6 - manometer; 7 - thermometer; 8 - flow meter; 9 - oxygen meter probe starting mechanism; 10 -support platform; 11 - oxygen meter probe 


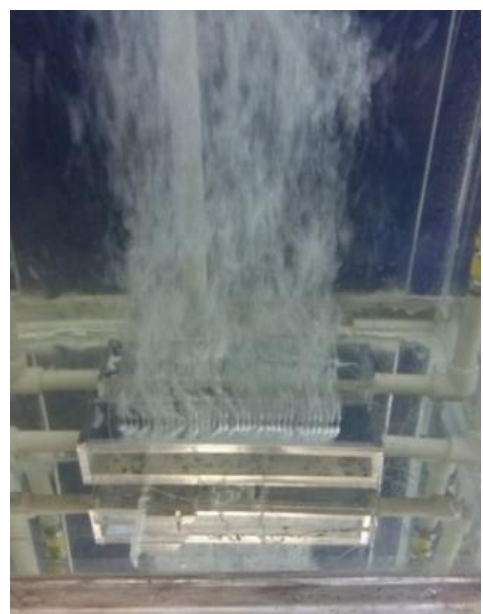

Figure 9: One fine bubble generator in operation

When measuring the dissolved oxygen concentration in water, the FBG is removed from the tank and the oxygen meter is inserted; it must be rotated with $0.3 \mathrm{~m} / \mathrm{s}$ is [20] [21] [22] [23] [24]. The operating principle of the oxygen meter is based on the electrical method [25] [26].

Following the measurements the data from Table 2 was obtained.

Table 2. Concentration values in time for the injection of atmospheric air

\begin{tabular}{|c|c|c|c|c|c|c|c|}
\hline $\begin{array}{c}\tau \\
{[\min ]}\end{array}$ & $\begin{array}{c}\dot{V}_{a i r} \\
{\left[\mathrm{dm}^{3} / \mathrm{h}\right]}\end{array}$ & $\begin{array}{c}\dot{V}_{O_{2}} \\
{\left[\mathrm{dm}^{3} / \mathrm{h}\right]}\end{array}$ & $\begin{array}{l}t_{H 2 O} \\
{\left[{ }^{\circ} \mathrm{C}\right]}\end{array}$ & $\begin{array}{c}t_{\text {air }} \\
{\left[{ }^{\circ} \mathrm{C}\right]}\end{array}$ & $C_{0}\left[\mathrm{mg} / \mathrm{dm}^{3}\right]$ & $C_{s}\left[\mathrm{mg} / \mathrm{dm}^{3}\right]$ & $C\left[\mathrm{mg} / \mathrm{dm}^{3}\right]$ \\
\hline 0 & \multirow{9}{*}{600} & \multirow{9}{*}{126} & \multirow{9}{*}{23.7} & \multirow{9}{*}{24.1} & \multirow{9}{*}{5.84} & \multirow{9}{*}{8.4} & 5.84 \\
\hline 15 & & & & & & & 6.89 \\
\hline 30 & & & & & & & 7.65 \\
\hline 45 & & & & & & & 8.01 \\
\hline 60 & & & & & & & 8.10 \\
\hline 75 & & & & & & & 8.26 \\
\hline 90 & & & & & & & 8.31 \\
\hline 105 & & & & & & & 8.35 \\
\hline 120 & & & & & & & 8.39 \\
\hline
\end{tabular}

The value of $\mathrm{C}_{\mathrm{s}}$ in Table 2 was chosen from Table 1 according to the water tank temperature.

Based on the data in Table 2, the graph in Figure 10 was plotted.

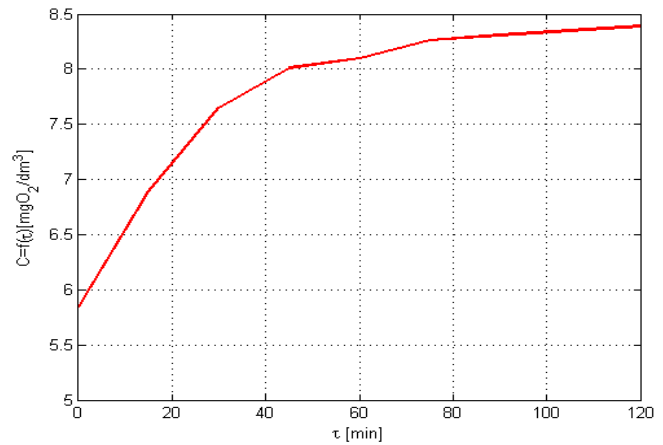

Figure 10: The function $C_{O_{2}}=f(\tau)$ graphic representation
The comparison of the theoretical results (Figure 6) with the experimental data is represented in Figure 11.

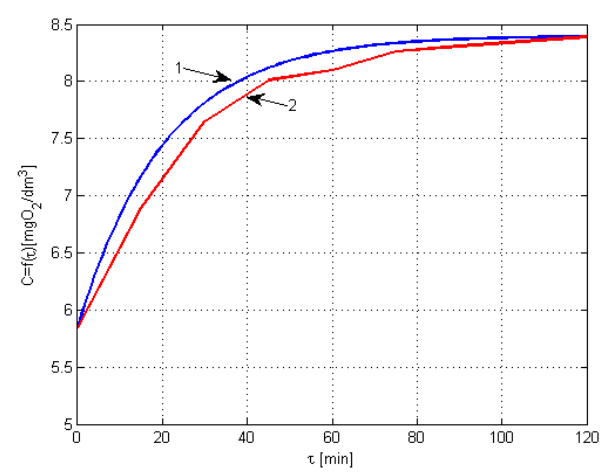

Figure 11: Variation of oxygen dissolved in water in time

1 - curve based on theoretical data, 2 - curve based on experimental data 
Figure 11 shows a good coincidence between the theoretical and the experimental ones, which demonstrates a high quality of the researches on water aeration. The results of the researches presented in the paper coincide with similar data in the literature [27] [28] [29] [30] [31].

\section{Conclusions}

The design and construction of this fine bubble generator has led to a new solution to increase the oxygen transfer rate to water.

The FBG construction is simple and safe to operate because it has no mechanical moving elements.

Pressure drops that occur when air passes through FBG are smaller than porous diffusers, which leads to energy savings for air compression.

Experimental results satisfactorily validate the data obtained theoretically.

\section{Acknowledgements}

This work was supported by a grant of the Romanian National Authority for Scientific Research and Innovation, CCCDI - UEFISCDI, project number Manunet - MNET17/ENER2307 - CEBIOTREAT, within PNCDI III.

\section{References}

[1] Lăcrămioara Diana Robescu, Modelarea Proceselor Biologice de Epurare a apelor uzate, Editura POLITEHNICA Press, București 2009.

[2] D. Robescu, D. L. Robescu, A. Verestoy, Fiabilitatea proceselor, instalaţiilor şi echipamentelor de tratare şi epurare a apelor, Ed. Tehnică, Bucureşti, 2002.

[3] G. Oprina, I. Pincovschi, Gh. Băran, Hidro-GazoDinamica Sistemelor de aerare echipate cu generatoare de bule, Ed. POLITEHNICA PRESS, București, 2009.

[4] I. M. Căluşaru, N. Băran, Al. Pătulea, The influence of the constructive solution of fine bubble generators on the concentration of oxygen dissolved in water, Advanced Materials Research, Trans Tech Publications, Switzerland, vols. 538541, 2012, pp .2304-2310.

[5] Gh. Băran, N. Băran, Hidrodinamica bulelor generate de difuzori poroşi, Revista de Chimie vol.54, nr.5/2003, pag. $436 \div 440$.

[6] Gabriela Oprina, Florentina Bunea, Irina Pincovschi, Lucian Mândrea. Aspects of hydrodynamics and mass transfer in diffused aeration systems, Environmental Engineering and Management Journal April 2010, Vol. 9, No.4, 565-571.

[7] I. M. Căluşaru, N. Băran, Al. Pătulea, The influence of the constructive solution of fine bubble generators on the concentration of oxygen dissolved in water, Advanced Materials Research, Trans Tech Publications, Switzerland, vols. 538541, 2012, pp .2304-2310.

[8] G. Oprina, Contribuţii la hidro-gazo-dinamica difuzoarelor poroase, Teză de doctorat, Universitatea POLITEHNICA din Bucureşti, Facultatea de Energetică, 2007.

[9] G. M. Mateescu, Hidro-gazo-dinamica generatoarelor de bule fine, Teză de doctorat, Universitatea POLITEHNICA din Bucureşti, Facultatea de Mecanică şi Mecatronică, București, 2011.

[10] Elena Beatrice Tănase, Influența coompoziție gazului insuflat în apă asupra conținutului de oxigen dizolvat, Teză de doctorat, Universitatea POLITEHNICA din Bucureşti, Facultatea de Inginerie Mecanică și Mecatronică, 2017.

[11] I. Pincovschi, Hidrodinamica sistemelor disperse gaz-lichid, Teză de doctorat, Universitatea POLITEHNICA din București, 1999.

[12] Schierholz, E. L., Gulliver, J. S., Wilhelms, S. C., and Henneman, H. E. Gas transfer from air diffusers, Water Res., vol.40, no.5, 1018-1026, 2006.

[13] Băran Nicolae, Căluşaru Ionela Mihaela, Mateescu Gabriela, Influenţa arhitecturii generatoarelor de bule fine asupra variaţiei concentraţiei de oxigen dizolvat în apă, Lucrările celei de a şaptea conferinţe a hidroenergeticienilor din Romania Dorin Pavel, Bucuresti, 2012.

[14] Daniel Besnea, Gheorghe I. Gheorghe, Mihaela Constantin, Nicolae Băran, Beatrice Tănase, Researches regarding the placement of fine bubble generators in water tanks, 8th International Conference on Innovations, Recent Trends and Challenges in Mechatronics, Mechanical Engineering and New High-Tech Products Development MECAHITECH'16 International Conference, Bucharest, Romania, September 8th-9th, 2016, pp. 42-47.

[15] I. M. Căluşaru, Influența proprietăţilor fizice ale lichidului asupra eficienţei proceselor de oxigenare, Teză de doctorat, Universitatea Politehnica din București, 2014.

[16] Ionela Mihaela, Căluşaru Nicolae Băran, Alexandru Pătulea, Gabriela Mateescu, Theoretical and experimental researches regarding the modification of dissolved oxygen concentration in stationary waters, INnovation and Collaboration in Engineering Research, Romania (INCER-2012)CD, București, 2012.

[17] Alexandru Pătulea, Ionela Mihaela Căluşaru and Nicolae Băran, Researches regarding the measurements of the dissolved concentration in water, Advanced Materials Research Vols. 550553 (Advances in Chemical Engineering II)(2012) pp. 3388-3394C (2012) Trans Tech Publications, Switzerland doi:10.4028/ www.scientific.net/AMR.550-553.3388 
[18] N. Băran, Al. S. Pătulea, I. M. Călușaru, Computation of performance and efficiency of the water oxygenation process in non-stationary conditions, Ecological Engineering and Environment Protection, nr. 3, pp. 73-78, 2012.

[19] D. Houcque R. R. McCormick, Applications of MATLAB: Ordinary Differential Equations (ODE), School of Engineering and Applied Science North western University, Illinois, 2007.

[20] E. C. Gh. Isbăşoiu, Tratat de mecanica fluidelor, Editura Agir, București, 2011.

[21] F. M. White, Fluid mechanics, McGraw Hill inc, ISBN 9780077422417, New York, 2011.

[22] B. Tănase, M. Constantin, R. Mlisan (Cusma), R. Mechno, N. Băran, Water oxygenation using gas mixtures, Septième édition du Colloque FRancophone en Energie, Environnement, Economie et Thermodynamique - COFRET'16, CD, Bucarest, UPB - 29 - 30 juin, 2016.

[23] Zaid Abulghanam, Daniel Besnea, Nicolae Băran, Alexandru Sorin Patulea, Researches Regarding The Construction of A Mechanism Used For The Displacement of A Oxygen Meter Probe, Scientific Buletin Series D: Mechanichal Engineering , University POLITEHNICA of Bucharest, vol. 73, Issue 2, Editura Politehnica Pres, ISSN 1454-2358, pag. 161-170, Bucuresti, 2011.

[24] Nicolae Băran, Daniel Besnea, Despina Duminică, Iulian Avarvarei, Alexandru Sorin Patulea, Mechanism For The Displacement of An Oxygen Meter Probe In Stationary Waters, 3rd International Conference on Electronics Computer Technology (ICECT 2011),vol. 1, Editura IEEE Press,IEEE nr. Catalog CFP1195FART, ISBN 978-1-4244-8677-9, pag. 283-286, 810 aprilie, Kanyakumari, India, 2011.
[25] Alexandru Pătulea, Nicolae Băran, Ionela Mihaela Căluşaru, Measurements of Dissolved Oxygen Concentration in Stationary Water, World Environment (Scientific \& Academic Publishing) p-ISSN: 2163-1573, e-ISSN: 2163-1581,2012; 2(5): 104-109, doi: 10.5923/j.env.20120205.02, Rosemead, CA, 91731, USA, 2012.

[26] Al. Pătulea, N. Băran, I. M. Căluşaru, Measurements of Dissolved Oxygen Concentration in Stationary Water, World Environment, vol. 2(4), pp. 106-109 2012.

[27] N. Băran, I. M. Căluşaru, G. Mateescu, Influence of the architecture of fine bubble generators on the variation of the concentration of oxygen dissolved in water, Buletinul Stiintific al Universitatii POLITEHNICA din Bucuresti, Ed.Politehnica Press, seria D, Inginerie Mecanică, vol.75, nr. 3/2013, pp. 225-236.

[28] G. Mateescu, A. Marinescu, N. Băran, A new Constructing Fine Bubles Generators, Bulletin Of The Transilvania University of Braşov, vol.2, 2009, pp.359-367, Braşov.

[29] Gh. Băran, I. Pincovschi, F. Bunea, Performanţe ale generatoarelor de bule fine, Revista

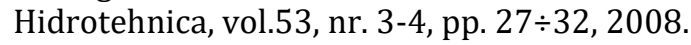

[30] I. M. Căluşaru, N. Băran, Al. Pătulea, Determination of dissolved oxygen concentration in stationary water, Revista de chimie, vol. 63, nr. 12 /2012, pag . $1312-1315,2012$.

[31] O.Dontu, C.I.Moga, B.Tanase, N.Baran, G.I.Gheorghe, E.Moraru, Researches regarding the use of additive technologies in the construction of waer aeration elements, International Journal of Mechatronics and Applied Mechanics, 2018, Issue 3, pp. 7-12.

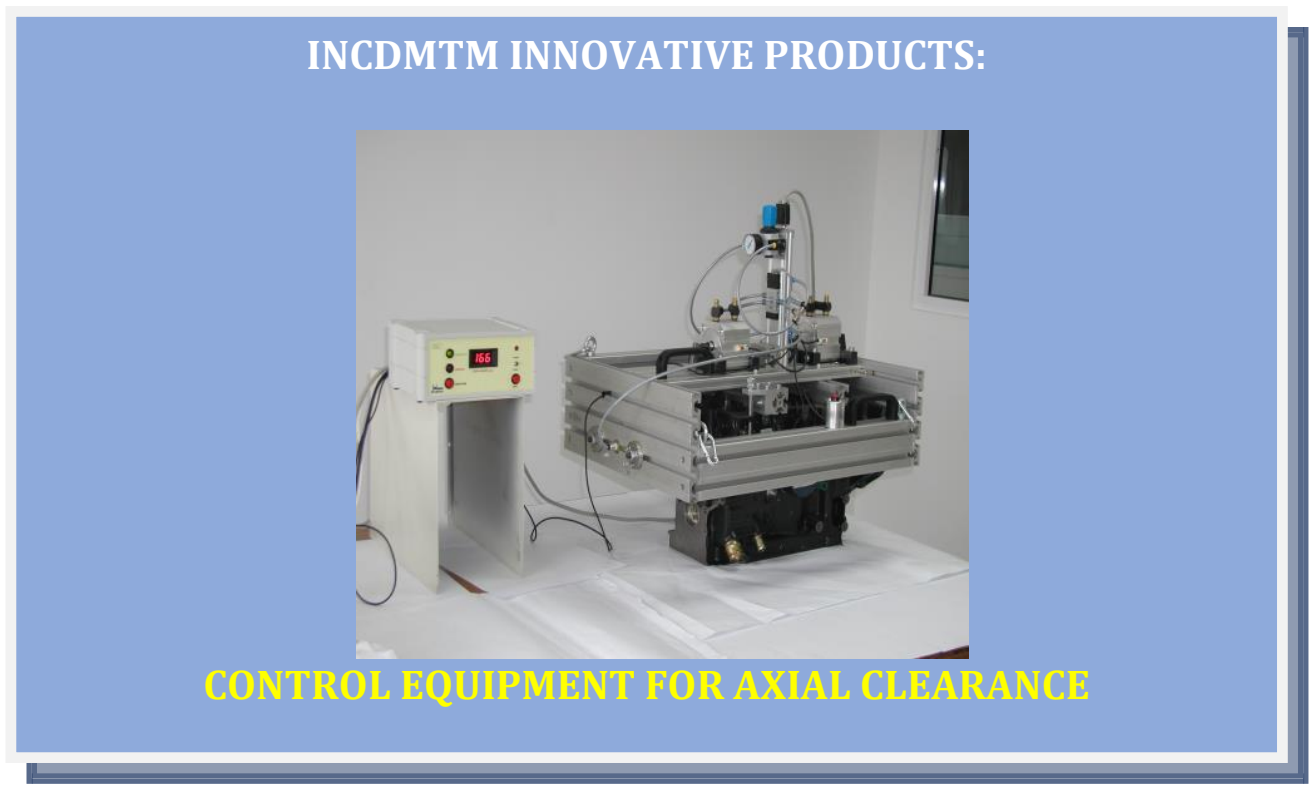

